\title{
Intellectual Property Rights in Animal Biotechnology
}

\begin{abstract}
Intellectual property is the foundation of innovations. The science of animal biotechnology has progressed vastly during past three decades. Vaccines, antibodies, gene-editing, or transgenic animals as model for investigating human diseases and producing recombinant therapeutics, and the bioinformatics methods are the innovative intellectual outcomes.
\end{abstract}

\section{Highlights}

- Animal biotechnology is oriented toward developing products at commercial scale

- IPRs are essential components of animal biotechnology research and development.

\section{Keywords}

Intellectual property $\cdot$ Patents $\cdot$ Copyrights $\cdot$ Diagnostics $\cdot$ Recombinant vaccines •

Genetically modified organisms

\subsection{Introduction}

Use of biotechnology is not a new concept. Humans have used biotechnology since the dawn of civilization. The practice of animal biotechnology began more than 8000 years ago with the domestication and selective breeding of animals. Invention of genetic code in the mid-1950s pioneered the present concept of animal biotechnology.

Initially, the biotechnology progressed at slow pace and remained a subject of little attention. Development of techniques viz., genetic engineering or recombinant DNA (rDNA) techniques, cell culturing and manipulation, cell fusion, production of monoclonal antibodies, and gene-editing heralded a new era of revolution in biomedical sciences.

Meanwhile, it was realized that above innovations in conjunction with reproduction technologies could modify the cells, embryos, and animals, and indeed, the outcomes were amazing. This initiated the concerns about intellectual property and its protection in biotechnology applied to animals.

At present, the animal biotechnology is a major area of basic and applied biological research aimed to develop veterinary vaccines, molecular diagnostics, transgenic or gene-edited animals for diagnosis of human diseases, using genetically engineered animals for therapeutics and organs. All this involves intellectual inputs, and outcomes are of enormous economic importance. 


\subsection{What Is Intellectual Property?}

The term intellectual property (IP) is generic legal term that describes various types of intangible assets and laws which protect the innovations and applications of thoughts, ideas, and information of profitable value. In broader sense, IP protection is about the laws related to patents, copyrights, trademarks, trade secrets, and other similar rights (Cornish 1989).

Currently, a number of processes and methods applied to biotechnology are under legal protection, and most of the processed initiated in the USA. Later on, other countries also started competing in new biotechnological markets. It became important to them to amend their national laws in order to protect and boost investment in biotechnology. Despite the fact that international consensus is lacking on how biotechnology has to be treated, the biotechnology innovators opt for patenting their invention.

Webber (2003) has insisted that research outcomes of pharmaceutical sector, any biotech start-up or academia should be protected by patents. This is because enormous efforts, hard work, and financial inputs are needed to develop a novel drug or product out of hundreds and thousands of lead compounds. It is therefore prerogative for a company or institute to protect their innovative products from unauthorized duplication (Raj et al. 2015).

The patenting grants legal, time-bound monopolies to the eligible scientists or inventors (Murphy et al. 2015). Similarly, the trade secrets (information related to a formula, compilation, device or program or technique) can be protected by law that varies depending on a country and its legislation. The owner of trade secret is known as originator.

\subsection{Intellectual Property Laws}

Science plays key role in economic prosperity of the nation. Economy is strong when science and technology are allowed to do well. It is the technology that delivers goods and services, hence, directly or indirectly, the science is correlated to generate the revenue.

The very basic purpose of IP protection is to allow the right holder to prohibit others from using the IP (patents, copyrights, trademarks, and trade secrets) rights in well-defined ways (Brown 2003).

Activities of practicing scientist inextricably intersect with business world (Poticha and Duncan 2019). Some inventions are protected by various types of IP protection. It is important to take into consideration the business and legal factors before opting for a particular strategy (Voss et al. 2017). Some IPs are protected by simple regulatory norms, others need stringent IP protection (Voss et al. 2017).

\subsection{Types of IPs in Animal Biotechnology}

\subsubsection{Patenting Genetically Modified Organisms}

Patents cover various technologies used to modify mice or rat genome and the stem cells. For instance, the French institute CERBM and IGBMC (Centre Européen de Recherche en Biologie et en Médecine-L'Institut de génétique et de biologie moléculaire et cellulaire) have patents of describing the use of the drug tamoxifen to induce Cre recombinase activity in vivo in a transgenic mouse (https://www. taconic.com/taconic-insights/model-generationsolutions//biotechnology-patents-and-gmos.html, accessed on Feb. 26, 2019). The US Patent Office had granted a patent (No. US4736866), for a transgenic mouse model, named "Oncomouse," whose germ and somatic cells carry recombinant activated oncogene (https://patents.google.com/ patent/US4736866A/en, accessed on Feb. 26, 2019). The transgenic mouse was developed at Harvard Medical School (Brown 2000).

By 2004, around 600 animal patents had been granted worldwide, $80 \%$ in the USA, and most relating to "animal models" for biomedical investigations. Besides the USA and European 
Union, only three countries had allowed patents for experimental animals (Lesser 2006).

\subsubsection{IP Issues in In Silico Biology}

Bioinformatics and in silico methods are indispensable tools to analyze gigantic "omics" sequence data. The bioinformatics programs are used to predict hypothetical gene, proteins, and metabolic pathways from the sequence data of microorganism (Singh et al. 2017; Sharma et al. 2018). In silico methods are used in computational modeling in medicinal computational chemistry, predicting drug-target interactions and developing (Quantitative) Structure-Activity Relationships ((Q)SARs) (Duardo-Sánchez et al. 2008).

Potentially patentable bioinformatics programmes include lines of code, algorithms, data content, data structure, and user interfaces (Harrison 2003). Several bioinformatics algorithms are available for analyzing sequence data and predicting genes and proteins from the data. Many of them are freely accessible while others need payments. Some commercial companies provide services to analyze the sequence data. Success or failure of bioinformatics and in silico biology needs the appropriate use of legal tools for protecting and utilizing the intellectual property. Patenting of products discovered using in silico procedures is still a debatable issue and needs a due attention.

\subsubsection{Therapeutics and IP}

Vaccines, monoclonal antibodies, and antibiotics provide protection against infectious diseases. As there are many forms of vaccines, and components of vaccines, delivery systems, and distribution networks, a variety of IP protections are applicable to vaccines (Durell 2016). With advances in understanding molecular biology of viruses, there is increase in the application of virus sequences and viral gene expression strategies to diagnose and treat the diseases. This extends the scope of patenting multiple constituents of vaccines (Venkataraman et al. 2017). Patents have also been granted for recombinant antigen-based rapid sero-diagnosis of viral infectious diseases, synthetic peptide antigens, and multiple antigenic peptide (MAP) assays for detecting viral infectious diseases of livestock.

\subsection{Outlook and Challenges}

Applications of biotechnology and molecular biological tools in animal sciences have reached new horizons. In present scenario, the transgenic animals have a large role in developing pharmaceutical industries and medicinal research. Developed countries have already realized potential of biotechnology-oriented industries and the importance of patenting the genetically modified animals.

Surprisingly, the world's richest biodiversity is present in countries that are poor, and lack resources and necessary wherewithal to transform their bioresources into products and earn the revenue. Also, the deprived or developing countries are unable to invest revenue to promote the research and provide adequate patent protection for genetically modified animals.

The legal costs involved in IP can be minimized by strategic planning and diligence. Due to high-controversial nature and processes involved in legal grant of protection for animal biotechnology, the short-term developments are likely to take place at national and regional levels. We emphasize whether a person works in a biotech start-up or a university or in commercial pharmaceutical company, a sound knowledge of patent system is necessary to protect the outcomes of novel research process or the end product.

IP impinges on almost every invention a scientist does. Scientists and researchers working in the fields of animal biotechnology and genetic engineering, however, need training to deal with complex issues of IP, their rights and obligations. 


\subsection{Conclusions}

Protecting IP by law is elemental right of an inventor to protect and utilize their invention for commercial use. The patents protect intellectual property by granting inventors the right to prevent others from making, utilizing, or commercial use of their invention. Computational and in silico biology, genome sequencing, gene synthesis, regenerative medicine, and genome engineering have enabled humans to utilize animals for qualitative and quantitative production of food and therapeutics. Although each country has its own procedures to define and evaluate the inventions and permit their patenting.

\section{References}

Brown C (2000) Patenting life: genetically altered mice an invention, court declares. CMAJ 163(7):867-868 (No abstract available)

Brown WM (2003) Intellectual property law: a primer for scientists. Mol Biotechnol 23(3):213-224 (Review)

Cornish WR (1989) Intellectual property: patents, copyright, trade marks, and allied rights. 2nd ed. London: Sweet \& Maxwell

Duardo-Sánchez A, Patlewicz G, López-Díaz A (2008) Current topics on software use in medicinal chemistry: intellectual property, taxes, and regulatory issues. Curr Top Med Chem 8(18):1666-1675

Durell K (2016) Vaccines and IP rights: a multifaceted relationship. Methods Mol Biol 1404:791-811. https:// doi.org/10.1007/978-1-4939-3389-1_52

Harrison R (2003) Protecting innovation in bioinformatics and in-silico biology. BioDrugs 17(4):227-231
Lesser W (2006) Living organism (animal) patents. Reviews in Cell Biology and Molecular Medicine. https://doi.org/10.1002/3527600906.mcb.200400043

Murphy A, Stramiello M, Lewis S, Irving T (2015) Introduction to intellectual property: A U.S. perspective. Cold Spring Harb Perspect Med 5: a020776. https://doi.org/10.1101/cshperspect.a020776

Poticha D, Duncan MW (2019) Intellectual property-the foundation of innovation. J Mass Spectrom. https:// doi.org/10.1002/jms.4331

Raj GM, Priyadarshini R, Mathaiyan J (2015) Drug patents and intellectual property rights. Eur J Clin Pharmacol 71(4):403-409. https://doi.org/10.1007/ s00228-015-1811-5 (Epub 2015 Feb 3)

Sharma D, Sharma A, Verma SK, Singh B (2018) Targeting metabolic pathways proteins of Orientia tsutsugamushi using combined hierarchical approach to combat scrub typhus. J Mol Recognit 21:e2766. https://doi.org/10.1002/jmr.2766

Singh G, Sharma D, Singh V, Rani J, Marotta F, Kumar M, Mal G, Singh B (2017) In silico functional elucidation of uncharacterized proteins of Chlamydia abortus strain LLG. Future Sci OA 3(1):FSO169. https://doi.org/10.4155/fsoa-2016-0066 (eCollection 2017 Mar. Erratum in: Future Sci OA. 2017 Oct 05;3(4):FSO66C1)

Venkataraman S, Ahmad T, Haidar MA, Hefferon KL (2017) Recently patented viral nucleotide sequences and generation of virus-derived vaccines. Recent Pat Antiinfect Drug Discov. 12(1):31-43. https://doi.org/ 10.2174/1574891X12666170619102506

Voss T, Paranjpe AS, Cook TG, Garrison NDW (2017) A Short Introduction to Intellectual Property Rights. Tech Vasc Interv Radiol. 20(2):116-120. https://doi. org/10.1053/j.tvir.2017.04.007

Webber PM (2003) A guide to drug discovery. Protecting your inventions: the patent system. Nat Rev Drug Discov. 2(10):823-830 